\title{
Impact of the Financial Crisis on Accounting Conservatism
}

\author{
Rim El Houcine \\ Higher Commercial Studies of Sousse, Tunisia \\ International Finance Group Tunisia \\ 79 Route de la Plage 4011 Hammam Sousse- TUNISIE \\ Tel: 216-5835-0993 E-mail: rimelhoucine@yahoo.fr
}

Received: July 5, $2021 \quad$ Accepted: Nov. 17, $2021 \quad$ Published: December 1, 2021

doi:10.5296/ajfa.v13i2.18930 URL: https://doi.org/10.5296/ajfa.v13i2.18930

\begin{abstract}
This paper analyzes the financial crisis effect on French companies accounting conservatism. The study is conducted on a sample of 120 French firms, observed from the year 2005 to 2009. We used the Basu model (1997) to test the effect of the financial crisis on the level of accounting conservatism pre-crisis (2005-2007) and during the crisis (2008-2009).

The results showed that companies during the crisis period are not conservative. Managers will tend to be more aggressive by reporting the good news and delaying the recognition of the bad. The effect of the financial crisis is still an important topic to study. In that regard, this study is important. It contributes to the understanding of the relationship between accounting conservatism and financial crisis.

The main limitation of the present study is that it limited to the effects in Frensh listed companies.
\end{abstract}

Keywords: Accounting conservatism, Financial crisis, French companies 


\section{Introduction}

This article focuses on the effect of the financial crisis on the level of accounting conservatism in the French context. Indeed, despite the wealth of studies related to our problematic, in the context of Central and Eastern Europe countries, including developing countries. In France, few studies contribute to the understanding of this theme. Thus, the majority of articles have studied the effect of the 1997 Asian financial crisis on accounting conservatism.

This work has, therefore, the ambition to provide additional light on a current topic, still very little discussed in France, about the effect of the financial crisis (2008-2009) on accounting conservatism. The study is estimated on a sample of 120 French companies listed on the SBF 120 index over five years from 2005-2009 to 600 observations. The final example includes 400 observations. The remainder of this paper is organized as follows:

Section 1 reviews the relevant literature. Section 2 discusses the research methodology and sample, and Section 3 presents the results. The final section concludes.

\section{Literature Review}

The effect of financial crisis study (2008-2009) on the level of accounting conservatism in the EU and in particular, in France, is still limited since there is no research done in this context. On the other hand, some studies have analyzed the association between accounting conservatism and earnings management in the European context during the financial crisis (2008-2009).

Balakrishnan and al. (2016) study the effect of accounting conservatism on the level of the company's investment during the financial crisis (2007-2008). They find that companies with less conservative financial reporting experienced a sharper decline in investment activity following the onset of the crisis than firms with more conservative financial reporting. In other words, the investment was more sensitive to a negative credit market shock for companies with aggressive financial reporting. This relationship is stronger for companies that were financially constrained is faced with more significant external financing needs or had a higher information asymmetry. They also find that more conservative firms recorded lower declines in debt-raising activity than in stock market performance. The evidence suggests that accounting conservatism reduces underinvestment in the presence of information frictions.

Filip and Raffournier (2012) examine the impact of the financial crisis (2008-2009) on the earnings management behavior of European-listed firms. They noticed that there was a significant decrease in income smoothing and an improvement of accruals quality during the crisis period. This trend was confirmed in most of the 16 countries studied.

Iatridis and Dimitras (2013) study how the economic crisis is affecting the possibilities of results manipulation, and the relevance of the financial figures of the listed companies: Portugal, Ireland, Italy, Greek, and Spanish that are audited by a Big4. They found that Portugal, Italy, and Greece tend to be more involved in earnings management to improve 
their profitability and liquidity during the 2008 financial crisis, while Ireland has less evidence of manipulation results than Spain.

Similarly, in the context of the 2008 financial crisis, Francis and al. (2013) tested how conservative accounting affects shareholder value. They found that there is a significant positive relationship and an economically important relationship between conservatism and stock performance during this period. They found that there is a meaningful positive relationship and a financially significant relationship between conservatism and stock performance during this period.

Kousenidis and al. (2013), taking a sample of EU companies, examined how the 2008 financial crisis impacted the quality of reported earnings of listed companies in countries with low tax sustainability. The results show that the average of earnings quality improved during the financial crisis.

The financial crisis is a factor that influences the extent of conservatism practiced by managers. Warganegara and Vionita (2010) examine the effects of the Asian financial crisis over the period 1996-2001 on the levels of accounting conservatism in Indonesia. They show that the pessimism of investors is dominated, and all good news has been covered with bad news. Most investors respond to bad news by further reducing companies' access to capital. In an attempt to deal with these adverse reactions, managers have an incentive to recognize more accurate information than they would typically (Francis and al., 2013). In such a case, the manager will choose a more aggressive conservatism during the financial crisis.

At the same time, using conditional conservatism, Wu and al.(2013) studied the effect of accounting conservatism on shareholder value during the 2007 financial crisis. The method he used to detect conservatism is the C-score of Khan and Watts (2009), who used cumulative stock returns as a proxy for the value of the firm. By choosing a sample of 5500 American companies, they found that there is a positive association between conservatism and stock returns. They used substitutes for conservatism, different start dates of the crisis, non-financial companies in the sample, and various statistical methods, making this result stronger. Subsequently, this finding provides proof positive theory accounting that conservatism is an effective governance mechanism to mitigate the information and control risk for agency problems, and that shareholders benefit from prudent accounting.

Many empirical studies have attempted to quantify the extent of accounting conservatism and to identify the main advantages of conservatism.

Watts (2003a) debates the implications of accounting conservatism on accounting regulators. He considers alternative explanations for accounting conservatism: contracting, shareholder litigation, taxation, and accounting regulation.

The majority of articles find that the conservatism of profits varies according to the characteristics and companies' economic context. According to Ryan (2006), business characteristics include primarily: high technology firms versus low technology firms, the composition of the board, public and private companies, the size of an auditor, the extent of profit management, the size of the company, and besides, the most studied economic contexts 
are fiscal quarters and countries.

However, few previous studies are exploring the impact of the business cycle on profit conservatism or the effect of the economic crisis on conservatism.

Khurana and al. (2006) found that firms present less conditional conservatism during expansionary periods and argue that the penalty for reporting bad news is more significant when the economy is expanding. As a result, companies have more incentives to delay the recording of bad news during the expansion of the economy.

Jenkins and al. (2009) demonstrated that conservatism is indeed higher during economic contractions from the year 1980-2003. They provided several critical explanations for these empirical results. First, securities litigation generally occurs in a period of economic decline, and the risk of litigation is one of the essential factors in the demand for conservative accounting (Watts 2003b). Second, the threat of increased regulatory review during the financial crisis motivates the submission of conservative accounting numbers. Third, the passage in funding sources from internal to external during the recession must result in increased demand for more conservative accounting information.

Nevertheless, many studies that have studied the impact of the 1997 Asian crisis on profit conservatism found evidence against the findings of Khurana and al. (2006) and Jenkins and al. (2009).

To summarize, there is mixed evidence of previous research on the impact of the company's cycle on accounting conservatism and an apparent lack of research on the effects of the 2007-2008 global financial crisis on conservatism.

Based on the theoretical arguments and empirical evidence presented, we assume that the level of conditional conservatism must be lower during periods of economic decline compared to periods of expansion for companies in Central and Eastern Europe. We anticipate that the risk of litigation is higher. As a result, regulatory review increases during the crisis period. As a result, they will not be essential factors of conservatism for Eastern European bank-oriented companies in Eastern and Central European countries due to the mechanisms of the undeveloped capital market.

Vichitsarawong and al. (2010) and Gul and al. (2002) report that accounting conservatism in East Asian countries is lower during the crisis than during regular economic periods. Thus, they assume that companies facing the financial crisis are under pressure to pass on more positive information to investors to reduce the negative impact of the crisis. Managers will tend to be more aggressive in reporting good news and delaying the recognition of bad news. As a result, the level of conservatism has decreased from the pre-crisis period to the crisis period. We can then state the following hypothesis: The level of accounting conservatism decreases in times of financial crisis. 


\section{Methodology}

\subsection{Sample and Data Collection}

The sample is composed by industrial and commercial companies belonging to the SBF 120 stock exchange index throughout an investigation from 2005 to 2009 . We collected the data covered by this study from the Thomson Financial database.

To study the level of accounting conservatism in times of crisis, we divided our sample into two sub-samples a Pre-crisis period (2005-2007) and during the crisis (2008-2009). Table 1 describes the sample.

Table 1. Description of the Sample

\begin{tabular}{|l|c|c|}
\hline & $\begin{array}{c}\text { Number Of } \\
\text { Compagnies }\end{array}$ & $\begin{array}{c}\text { Number Of } \\
\text { Observations }\end{array}$ \\
\hline Companies Listed On SBF 120 (Year 2005-2009) & 120 & 600 \\
\hline -Companies Belonging To The Financial Sector & 18 & 90 \\
\hline -Companies With Unavailable Data & 18 & 20 \\
\hline -Financial Statements Of Non-Consolidated Groups & 4 & 400 \\
\hline Final Sample & 80 & 20 \\
\hline
\end{tabular}

\subsection{Modeling Regression}

We used the Basu model (1997) to test the effect of the financial crisis on the level of accounting conservatism pre-crisis (2005-2007) and during the crisis (2008-2009). Basu model (1997) is called the differential timelines of earning concerning bad and good news. Basu (1997) considers accounting conservatism as the asymmetric treatment of good news as gains and bad as losses is captured by the linear regression of accounting earnings on stock returns. The Basu model (1997) applied is as follows:

We will integrate the size and debt variables in our model.

$$
\mathrm{X}_{\mathrm{it}} / \mathrm{p}_{\mathrm{it}-1}=\alpha 0+\alpha 1 \mathrm{D}_{\mathrm{it}}+\alpha 2 \mathrm{R}_{\mathrm{it}}+\alpha 3 \mathrm{D}_{\mathrm{it}} * \mathrm{R}_{\mathrm{it}}+\alpha 4 \mathrm{SIZE}+\alpha 5 \mathrm{DEBT}+\varepsilon_{\mathrm{it}}
$$

The coefficient $\alpha 2$ measures the rapidity of the recognition of benefits to good news (positive returns) and the sum of coefficients $\alpha 2$ and $\alpha 3$ measures the rapidity of the recognition of benefits to bad news (negative returns).

The coefficient of determination (R2) is measured by the association between earnings and positive stock market returns as well as between incomes, and adverse stock market returns So that the increase in the value of this coefficient implies that the association between the 
profit and the stock market return will then be more significant. In this context, Basu (1997) postulates that to measure the level of accounting conservatism, we must compare R2 with either bad news or good news.

We will apply the Basu model (1997) for the two sub-samples Pre-crisis (2005-2007) and during the crisis (2008-2009) to compare the coefficient $\alpha 3$ and even compare their respective R2.

\subsection{Variables Measurements}

\subsubsection{The Dependent Variable: Earnings per share to price ratio}

Our dependent variable, denoted by $\mathrm{X}_{\mathrm{it}} / \mathrm{P}_{\mathrm{it}-1}$ in the regressions, is the Earnings Per Share (EPS) ratio divided by the price given by the report of the accounting result per share on the share price at the beginning of the period. According to Christie (1987) and Kothari (1992), the regression of good quality and the control of the heteroscedasticity of the residues is due to the division of the accounting variables by the price at the beginning of the period.

Earnings Per share (EPS) the ratio of a company's net income to the number of shares that make up its capital. EPS is a ratio that companies listed under IFRS must present.

$$
\begin{aligned}
& \mathrm{X}_{\mathrm{it}} \text { : The earnings per share for firm } \mathrm{i} \text { in fiscal year } \mathrm{t} \text {. } \\
& \mathrm{P}_{\mathrm{it}-1} \text { : The price per share at the beginning of the fiscal year. } \\
& \mathrm{X}_{\mathrm{it}} / \mathrm{P}_{\mathrm{it}-1} \text { : Earnings per share to price ratio. }
\end{aligned}
$$

\subsubsection{The Independent Variable: Stock Returns}

The independent variable is the stock returns. Basu (1997) uses equity returns to represent good and bad news. Basu (1997) uses annual stock returns measured from nine months before fiscal year-end to three months after fiscal year-end. However, most subsequent studies use the fiscal year. The performance measure, three months after fiscal year-end, aims to give the market time to integrate information into contemporary profits. The use of the year's return prevents the yield from being distorted by the introduction of new information (different from benefits) on the market.

We have opted to calculate performance for the period beginning from the ninth month before fiscal year-end until the third month after fiscal year-end, using the following formula:

$$
\mathrm{R}_{\mathrm{it}}=\left(\mathrm{P}_{\mathrm{it}}-\mathrm{P}_{\mathrm{it}-1}\right) / \mathrm{P}_{\mathrm{it}-1} \quad \text { with: }
$$

$\mathrm{P}_{\mathrm{it}}$ : the share price $\mathrm{i}$ three months after fiscal year-end.

$\mathrm{P}_{\mathrm{it}-1}$ : the share price i nine months before fiscal year-end.

Easton, Harris, and Ohlson (1992) and Dumontier and Labelle (1998) have shown that the application of dividends for the adjustment of returns does not affect the result. We have adopted for the disregard of dividends concerning the calculation of stock market returns.

3.3.3. The Dichotomous Variable : Good or Bad News 
$\mathrm{D}_{\text {it }}$ worth 1 if the stock market return is negative (indicating bad news) and worth 0 if the stock market return is positive (good news).

Basu (1997) reveals that negative stock market returns over a period generally reflect net asset losses, and positive stock returns reflect net asset gains.

Gains that show increases in the value of net assets, whereas, losses show decreases in the value of net assets.

\subsubsection{Size}

The total market capitalization, that of the assets, the turnover, the accounting result, and the total number of employees present the various measures of company size cited by Bujak and Richardson (1997).

We opted for market capitalization as a measure of the size of the firm.

During our study, we used the Neperian logarithm of market capitalization to better linearize this measure because of the differences noted due to the heterogeneity of the sample.

\subsubsection{Indebtedness}

There are multiple measures of debt in the literature. Daley and Vigeland (1983) measure the level of debt by the ratio of total listed and unlisted debt or non-current debt/Total assets. For example, Black, Sellers, and Manly (1998) measure the level of indebtedness of the company by the ratio of Total non-current financial debt/equity. Also, Brown, Izan and Loh (1992) keep the total rate of financial debts by total liabilities and equity. Like Lafond and Watts (2008), we measure the level of debt by the Total Debt / Total Assets ratio.

\section{Analysis and Discussion of Results}

\subsection{Descriptive Statistics}

Table 2 presents the descriptive statistics of the ratio Earnings per share/price and share returns of subsample: Pre-crisis (2005-2007) and during the crisis (2008-2009). The earnings per share/price and share return variables show trends similar to those of previous research such as the Sodan, Barac, and Vurko study, 2013). 
Table 2. Descriptive Statistics for Subsamples « Financial Crisis »

\begin{tabular}{|c|c|c|c|c|c|}
\hline \multicolumn{6}{|c|}{ Pre-Crisis (2005-2007) } \\
\hline Variable & Median & Mean & Standard Deviation & Minimum & Maximum \\
\hline $\mathrm{X}_{\mathrm{it}} / \mathrm{P}_{\mathrm{it}-1}$ & 0.0626 & 0.0777 & 0.0635 & 0 & 0.5047 \\
\hline $\mathrm{D}_{\mathrm{it}}$ & - & 0.3437 & - & - & - \\
\hline $\mathrm{R}_{\mathrm{it}}$ & 0.0097 & 0.0095 & 0.0265 & -0.0784 & 0.1344 \\
\hline $\mathrm{D}_{\mathrm{it}} * \mathrm{R}_{\mathrm{it}}$ & 0 & -0.0059 & 0.0122 & -0.0784 & 0 \\
\hline SIZE & 0.0085 & 0.0084 & 0.0013 & 0.0055 & 0.0118 \\
\hline DEBT & 0.2428 & 0.2864 & 0.2168 & 0.0027 & 0.6908 \\
\hline \multicolumn{6}{|c|}{ During The Crisis (2008-2009) } \\
\hline Variable & Median & Mean & Standard Deviation & Minimum & Maximum \\
\hline $\mathrm{X}_{\mathrm{it}} / \mathrm{P}_{\mathrm{it}-1}$ & 0.0496 & 0.0469 & 0.0311 & 0 & 0.1695 \\
\hline $\mathrm{D}_{\mathrm{it}}$ & - & 0.475 & - & - & - \\
\hline $\mathrm{R}_{\mathrm{it}}$ & 0.0050 & 0.0049 & 0.0483 & -0.0925 & 0.1413 \\
\hline $\mathrm{D}_{\mathrm{it}} * \mathrm{R}_{\mathrm{it}}$ & 0 & -0.0182 & 0.0248 & -0.0925 & 0 \\
\hline SIZE & 0.0081 & 0.0081 & 0.0014 & 0.0047 & 0.0117 \\
\hline DEBT & 0.2368 & 0.2758 & 0.2004 & 0.0015 & 0.1535 \\
\hline
\end{tabular}

We find that the median Earnings per Share / Share Returns ratio before the financial crisis was higher during the crisis period. Besides, the earnings per share/price and share returns give significantly lower average values during the crisis than in the period before the financial crisis. These results are consistent with those of Sodan, Barac and Vurko (2013) which were found in the countries of Central and Eastern Europe, that the median of the ratio Earnings per share/ price and share returns before the financial crisis (2005-2007) were higher during the crisis period (2008-2009). 
Besides, we note that the standard deviation of earnings per share before the financial crisis is of the order of 0.0635 . During the crisis period, it is of the order of 0.0311 , which allows us to see a decrease in the standard deviation. On the other hand, it shows that the standard deviation of share returns during the crisis period was higher than before the crisis.

Finally, we find that the average size of companies and the level of indebtedness decreased during the financial crisis than before the crisis.

\subsection{Bi-Varied Analysis}

To find out if there is a problem of multi-collinearity between the explanatory variables, we have used the correlation matrix, which must affirm a multi-collinearity between some of the variables studied. There is no problem with multicollinearity if all dependent and independent variable coefficients are less than 80per cent (Kennedy, 1985).

Table 3 shows that all the correlation coefficients are less than 0.8 , and therefore, we can confirm the correlation between the variables. It means that the problem of multi-collinearity does not exist in our model.

Table 3. Correlation Matrix

\begin{tabular}{|c|c|c|c|c|c|}
\hline & $\mathbf{D}_{\mathbf{i t}}$ & $\mathbf{R}_{\mathbf{i t}}$ & $\mathbf{D}_{\mathbf{i t}} \mathbf{R}_{\mathbf{i t}}$ & $\mathbf{S I Z E}$ & DEBT \\
\hline $\mathbf{D}_{\mathbf{i t}}$ & 1 & & & & \\
\hline $\mathbf{R}_{\mathbf{i t}}$ & $\begin{array}{c}-0.7808^{* * *} \\
(0.0000)\end{array}$ & 1 & & & \\
\hline $\mathbf{D}_{\mathbf{i t}} \mathbf{R}_{\mathbf{i t}}$ & $\begin{array}{c}0.6974 * * * \\
(0.0000)\end{array}$ & $\begin{array}{c}0.7116 * * * \\
(0.0000)\end{array}$ & 1 & & \\
\hline SIZE & $\begin{array}{c}0.0718^{* * *} \\
(0.1520)\end{array}$ & $\begin{array}{c}-0.1438 * * * \\
(0.0039)\end{array}$ & $\begin{array}{c}0.0172 \\
(0.7314)\end{array}$ & & \\
\hline DEBT & -0.0592 & 0.0276 & -0.0035 & -0.0371 & \\
& $(0.2373)$ & $(0.5822)$ & $(0.9436)$ & $(0.4599)$ & \\
\hline
\end{tabular}

We find that the $D_{i t}$ is correlated negatively and significantly with the $R_{i t}(-0.7808)$, with the $D_{i t} * R_{i t} \quad(-0.6974)$ at the significance level of 1 per cent.

The share returns is positively correlated with the $D_{i t} * R_{i t}(0.7116)$ and negatively correlated with the size (-0.1438) at the significance level of 1 per cent.

The recognition of bad news relative to the recognition of good news generated by stock 
market returns $\left(D_{i t} * R_{i t}\right)$ is positively correlated with the size of the company $(0.0172)$ and negatively correlated with the indebtedness (-0.0035).

Finally, the size of the company is correlated negatively with the company's indebtedness $(-0.0371)$.

For our analysis to be more in-depth, we used the VIF (Variance Inflation Factor) which allows us to detect the problem of multi-colinearity between the explanatory variables. In our study, the average VIF of the variables is less than 5. Thus, we can confirm the hypothesis of the absence of multi-collinearity between the explanatory variables of our model.

\subsection{Multi-Varied Analysis}

The regression results of the two sub-samples in the panel are presented in Table 4: Pre-crisis (2005-2007) and during the crisis (2008-2009).

The coefficient $\alpha 3$ relative to $D_{i t} * R_{i t}$ measures the practice of accounting conservatism. We will examine the level of accounting conservatism of the coefficient $\alpha 3\left(D_{i t}{ }^{*} R_{i t}\right)$ before and during the crisis and also compare the adjusted R2 of the Basu model (1997) applied to the sample pre-crisis and during the crisis.

According to Table 4, we observe that before the financial crisis the coefficients $\alpha 2\left(R_{i t}\right)$ and $\alpha 3\left(D_{i t} * R_{i t}\right)$ are statistically significant at the respective thresholds of 1 per cent and 10 per cent. During the crisis period, we note that the coefficients $\alpha 1\left(D_{i t}\right)$ and $\alpha 3\left(D_{i t}{ }^{*} R_{i t}\right)$ are statistically significant at the 5 per cent threshold.

Initially, the coefficient of interaction $D_{i t} * R_{i t}(\alpha 3)$ is negative and significant at the 10 per cent threshold before the financial crisis, which implies that the gains are more sensitive to negative returns «bad news » than positive returns « good news ». Also, we notice during the crisis, that the coefficient $\alpha 3\left(D_{i t}{ }^{*} R_{i t}\right)$, lower compared to before the crisis, it is negative and significant at the threshold of 5 per cent. It means that companies during the crisis period tend to be more aggressive in reporting good news and delaying recognition of bad news.

Which means that companies are not conservative during this period. This may be due to companies under pressure to transmit more positive information to investors in order to reduce the negative impact of the crisis.

We note that the coefficient $\alpha 3\left(\mathrm{D}_{\mathrm{it}}{ }^{*} \mathrm{R}_{\mathrm{it}}\right)$ is lower during the financial crisis than before the crisis $(-0.8086<-0.6946)$. These latest results confirm, in the French context, that the level of accounting conservatism during the period of financial crisis is lower than before the crisis.

On the other hand. the coefficient of determination R2 of the Basu model (1997) applied to the sample Pre-crisis (R2=0.1742) is higher than the R2 of the Basu model (1997) applied to the sample during the crisis $(\mathrm{R} 2=0.1575)$. French companies integrate their economic losses during the crisis period (2008-2009) more than before the financial crisis and they quickly report the bad news of the losses. Based on this coefficient, French companies are less conservative during the period of financial crisis than before the crisis.

From the conclusions from coefficient $\alpha 3$ and the coefficient of determination R2, we can say 
that the hypothesis assuming that the level of accounting conservatism decreases during a crisis period is confirmed.

The size and debt variables have no significant impact during the pre-crisis period. On the other hand, the size variable is positive and significant at the 1 per cent level during the financial crisis.

Table 4. The Impact of the Financial Crisis on Accounting Conservatism: Basu Model (1997) Pre-Crisis model (2005-2007)

\begin{tabular}{lll}
\hline Variable & Coefficient & Probability \\
\hline Constant & $0.0692^{* * *}$ & 0.000 \\
\hline $\mathrm{D}_{\mathrm{it}}$ & -0.0021 & 0.827 \\
\hline $\mathrm{R}_{\mathrm{it}}$ & $0.5295^{* * *}$ & 0.007 \\
\hline $\mathrm{D}_{\mathrm{it}}{ }^{*} \mathrm{R}_{\mathrm{it}}$ & $-0.6946^{*}$ & 0.090 \\
\hline $\mathrm{SIZE}$ & -8.4094 & 0.801 \\
\hline $\mathrm{DEBT}$ & -0.0302 & 0.519 \\
\hline $\mathrm{N}$ & 240 & \\
\hline $\mathrm{R} 2$ & 0.1742 & \\
\hline
\end{tabular}

Model During The Crisis $\quad(2008-2009)$

\begin{tabular}{lll}
\hline Variable & Coefficient & Probability \\
\hline Constant & $0.0413^{* * *}$ & 0.000 \\
\hline $\mathrm{D}_{\mathrm{it}}$ & $-0.0189^{* * *}$ & 0.037 \\
\hline $\mathrm{R}_{\mathrm{it}}$ & -0.0479 & 0.780 \\
\hline $\mathrm{D}_{\mathrm{it}}{ }^{*} \mathrm{R}_{\mathrm{it}}$ & $-0.8086^{* *}$ & 0.018 \\
\hline $\mathrm{SIZE}$ & $4.7721^{* * *}$ & 0.005 \\
\hline $\mathrm{DEBT}$ & -0.0084 & 0.573 \\
\hline $\mathrm{N}$ & 160 & \\
\hline $\mathrm{R} 2$ & 0.1575 & \\
\hline
\end{tabular}




\section{Conclusion}

Empirical evidence concerning the role played by international accounting standards in the conservatism of financial statements reporting has proven inconclusive. This paper seeks to explore the impact of mandatory IFRS adoption on accounting conservatism in France in the period of financial crisis. The main limitation of the present study is that it limited to the effects in French listed companies. Indeed, we used the Basu model (1997) on a sample of 120 French firms during 2005-2009. We find evidence of a significant reduction of accounting conservatism during the financial crisis. The results showed that companies during the crisis period are not conservative. Managers will tend to be more aggressive by reporting the good news and delaying the recognition of the bad.

\section{References}

Balakrishnan.K., Watts.R. and Zuo. L. (2016). The Effect of Accounting Conservatism on Corporate Investment during the Global Financial Crisis. Journal of Business Finance and Accounting, 43(5-6), 513-542. https://doi.org/10.1111/jbfa.12206

Basu. S. (1997). The Conservatism Principle and the Asymmetric Timeliness of Earnings. Journal of Accounting and Economics, 24(1), 3-37. https://doi.org/10.1016/S0165-4101(97)00014-1

Black. E.L., Sellers. K.F. and Manly. T. S. (1998). Earnings Management Using Asset Sales: An International Study of Countries Allowing Noncurrent Asset Revaluation. Journal of Business Finance and Accounting, 25(9-10), 1287-1317. https://doi.org/10.1111/1468-5957.00238

Brown. P., Izan. H.Y., Loh. A.L. (1992). Fixed Asset Revaluations and Managerial lncentives. Abacus, 28(1), 36-57. https://doi.org/10.1111/j.1467-6281.1992.tb00268.x

Bujaki. M.L., Richardson. A.J. (1997). A Citation Trail Review of the Uses of Firm Size in Accounting Research. Journal of Accounting Literature, 16, 1-27. https://www.proquest.com/openview/2c20eea8ed6c69966ccfe56b8cae2c37/1?pq-origsite=gsc holar\&cbl=31366

Christie. A.A. (1987). On cross-sectional analysis in accounting research. Journal of Accounting and Economics, 9(3), 231-258. https://doi.org/10.1016/0165-4101(87)90007-3

Daley. L., Vigeland. R. (1983). The effects of debt covenants and political costs on the choice of accounting methods: the case of accounting for R\&D costs. Journal of Accounting \& Economics, 5(3), 195-211. https://doi.org/10.1016/0165-4101(83)90012-5

Dumontier. P., Labelle. R. (2010). Accounting earnings and firm valuation: the French case. The European Accounting Review, 7(2), 163-83. https://doi.org/10.1080/096381898336439

Easton. P.D., Harris. T. S. Ohlson. J. A. (1992). Aggregate accounting earnings can explain most of security retums: the case of long-term intervals. The Journal of Accounting \& Economics, 15(2-3), 119-142. https://doi.org/10.1016/0165-4101(92)90015-T 
Filip. A., Raffournier. B. (2014). The impact of the 2008-2009 financial crisis on earnings management: The European evidence. The International Journal of Accounting, 49(4), 455-478. https://doi.org/10.1016/j.intacc.2014.10.004

Francis. B., Hasan. I., \& Wu. Q. (2013). The benefits of conservative accounting to shareholders: Evidence from the financial crisis. Accounting Horizons, 27(2), 319-346. https://doi.org/10.2308/acch-50431

Gul. F., Srinidhi. B., Shieh. T. (2002). The Asian financial crisis. accounting conservatism and audit fees: Evidence from Hong Kong. SSRN Electronic Journal. https://doi.org/10.2139/ssrn.315062

Iatridis. G., Dimitras. A.I. (2013). Financial crisis and accounting quality: Evidence from five European countries. Advances in Accounting. incorporating Advances in International Accounting, 29(1), 154-160. https://doi.org/10.1016/j.adiac.2013.03.001

Jenkins. S., Kane. D., \& Velury. U. (2009). Earnings conservatism and value relevance across the business cycle. Journal of Business Finance \& Accounting, 36(9-10), 1041-1058. https://doi.org/10.1111/j.1468-5957.2009.02164.x

Khan. M., \& Watts. R.L. (2009). Estimation and Empirical properties of a Firm-Year Measure of Accounting Conservatism. Journal of Accounting and Economics, 48, 132-150. https://doi.org/10.1016/j.jacceco.2009.08.002

Khurana. I.K., Martin. X., Pereira. R., \& Raman. K.K. (2006). Economic state-varying incentives and timely recognition of economic losses. Working paper. University of Missouri-columbia. http://aaahq.org/AM2006/abstract.cfm?submissionID=467

Kothari. S.P. (1992). Information in prices about future earnings: Implications for earnings response coefficients. Journal of Accounting and Economics, 15(2-3), 143-171. https://doi.org/10.1016/0165-4101(92)90016-U

Kousenidis. D.V., Ladas. A.C., \& Negakis. C. I. (2013). The effects of the European debt crisis on earnings quality. International Review of Financial Analysi, 30, 351-362. https://doi.org/10.1016/j.irfa.2013.03.004

LaFond. R., \& Watts. R. (2008). The information Role of Conservatism. The Accounting Review, 83(2), 447-478. http://dx.doi.org/10.2308/accr.2008.83.2.447

Ryan. G. (2006). Identifying conditional conservatism. European Accounting Review, 15(4), 511-525. https://doi.org/10.1080/09638180601102099

Sodan. S., Barac. Z.A., \& Vuko. T. (2013). Lessons from financial crisis : Has accounting in Central and Eastern Europe become more conservative ? Economic research, 1, 399-414. https://doi.org/10.1080/1331677X.2013.11517659

Vichitsarawong. T.. Eng. L. L., \& Meek. G. (2010). The impact of the Asian financial $\S c r i s i s$ on conservatism and timeliness of earnings: Evidence from Hong Kong. Malaysia. 
Singapore and Thailand. Journal of International Financial Management and Accounting, 21(1), 32-61. https://doi.org/10.1111/j.1467-646X.2009.01035.x

Warganegara. D.L., \& Vionita. V. (2010). The effects of the Asian financial crisis on accounting conservatism in Indonesia. Asian Academy of Management Journal of Accounting and Finance, 6(1), 69-88. http://web.usm.my/journal/aamjaf/vol\%206-1-2010/6-1-4.pdf

Watts. R. (2003a). Conservatism in accounting part I: explanations and implications. Accounting Horizons, 17(3), 207-221. https://doi.org/10.2308/acch.2003.17.3.207

Watts. R. (2003b). Conservatism in accounting Part II: evidence and research opportunities. Accounting Horizons, 17, 287-301. https://doi.org/10.2139/ssrn.438662

Wu. Q., Francis. B., \& Hasan. I. (2013). The benefits of accounting conservatism to shareholders: evidence from the financial crisis. Accounting Horizons., 27(2), 319-346. https://doi.org/10.2139/ssrn.2291352 